\title{
The Effect of Using Digital Book to Ability Students' Reading in Descriptive Text at Tenth Grade SMA Negeri 2 Rantau Selatan
}

\author{
Shopiah Anggraini Rambe 1), Anna Leli Harahap ${ }^{2)}$, Rizki Lestari ${ }^{3)}$, Gustiani Pratiwi ${ }^{4)}$, Muhammad \\ Rusli ${ }^{5)}$, Nurhanna Harahap" ${ }^{6}$, Jupriaman ${ }^{7)}$ \\ 1,2,3,4,5,6,7)English Education Program, Al Washliyah University of Labuhanbatu \\ *Coresponding Author \\ Email : anggrainishopiah@gmail.com
}

\begin{abstract}
This study aims to see whether there is an effect of using a digital book on the reading ability of students in class X SMA Negeri 2 Rantau Selatan. This study uses a quantitative approach with a quasi-experimental method. The population in this study were all class X-MIA SMA Negeri 2 Rantau Selatan and the sample was taken by 72 students with simple random sampling technique. The data technique used a written test in the form of an essay, the instruments used were pretest and posttest. Based on the t-test analysis using SPSS version 22 for windows, it is found that the value of $t$ count $<$ t table $(1.241<1.667)$. This shows that the ability to overcome students' reading skills by using digital books is better than students who use conventional learning models. Therefore, learning using a digital book can be used in implementing English learning at SMA Negeri 2 Rantau Selatan for the 2020/2021 school year.
\end{abstract}

Keywords: Using of Digital Book, Reading Skils

\section{INTRODUCTION}

National education in Indonesia is, defined as a conscious and planned effort to create an atmosphere of learning and the learning process, so that students actively develop their potential so that they have religious spiritual strength, self-control, personality, intelligence, noble character, and skills that are needed both for themselves. Education is the most important thing for humans. In essence, education is a process of maturing children through interactions between teachers and students.The interaction of teachers and students is called the teaching and learning process. In teaching, the teacher must use the approach wisely so that what the teacher teaches can be easily understood to the child so that the child can solve what problems they consider difficult or difficult, especially in English lessons.

Along with the times followed by technological developments, the world of education has also developed. With the development of educational technology, teachers must be able to take advantage of currently developing technology in order to create innovative learning in the learning process.The development of science and technology enables all parties to obtain 
information quickly and easily from sources. Apart from developing rapidly, change is also happening rapidly. Therefore we need the ability to obtain, manage and utilize information to survive in changing circumstances. The importance of education in society in adapting to educational trends to create a society and society to increase competence, skills and more complete knowledge and unleash their full creative potential.

Almara'beh,Amer and Sulieman (2015: 761),state that the existence of multimedia technology can facilitate the educational process with tools and materials that can improveinteraction between teachers, students and learning media in an innovative wayin order to make the learning process more dynamic and applicable.E-book is an electronic version of a printed book that can be read on a personal computer or other device specially designed for reading e-books (Danang, 2009). E-book are books in digital form that can be read through an application.

E-book orelectronic book (or also digital book) isevolution from the printed books we are used to readingeveryday (Subiyantoro, 2014).Digital book, also known ase-book is a publication that consists offrom text, images, as well as sound andpublished in digital formcan be read on a computer or deviceother electronics such as android, or tablet (Andikaningrum et al. 2014).E-books are printed books that are converted into electronic forms to be read on a a monitor screen (Putu Laxman Pendit, 2008). Whalts states E-books are electronic versions of printed books that can be read on your own computer using an e-book reader.

Reading is one of the language skills which must be taught in language classroom.Fauziati (2010:32), states that reading text also provided opportunities for students to learn vocabulary, grammar, pronunciation and even good models for English writing- the way sentences, paragraphs, or texts are constructed.Reading is a complex and acomplex process. Complex means in the reading process involved various internal factors and factors external reader. Internal factors in the form of intelligence, interests, attitudes, talents, motivation, reading goals, and so on. External factors can be deep form of reading medium, social and economic background, and tradition read. Complicated means that external and internal factors are related forming complex coordination to support reading comprehension (Nurhadi, 2008: 13).

Based on previous research is Students' Reading Strategies to Answer Multiple Choice Questions of Reading Passage at the Third Grade of SMA Negeri 1 Klego Boyolali 2009/2010 Academic Year by Widati (2010), who found that the students did not use the appropriate strategies to answer multiple choice questions of reading passage. She also found that the question dealing with main idea is the easiest type of question, while the overall review question is the most difficult one for the third grade of SMA Negeri 1 Klego Boyolali 2009/2010 academic year. then previous research was taken from Khan and Pandian's work (2011) entitled A Study on Reading Comprehension Performance in English among Matriculation Students in Pakistan. It was stated in the research finding 4 that the reading performance of matriculation students was insufficient. It was found that only $41.81 \%$ respondents were successful to retrieve the main ideas from ten given short texts, it meant that $58.19 \%$ respondents were failed. It was concluded that the matriculation students were lack of comprehension when given the intensive reading tasks. And the last written by Ghafournia and Afghari (2013) entitled The Interaction between Cognitive Test-Taking Strategies, Reading Ability, and Reading Comprehension Test Performance of Iranian EFL Learners. They found that there is a relationship between the participants' level of reading proficiency and the using of cognitive test-taking strategies. The findings implied that the students in high level of reading 
proficiency used test-taking strategies as learning strategies to increase the comprehension, while the students in lower level used test-taking strategies as compensatory strategies to understand the reading texts and answer the questions.

The contents of the draft English course syllabus level SMA / MA / SMK / MAS in the 2013 curriculum, learning is designed forprovide experience in using English texts forunderstand and apply factual, conceptual, and procedural knowledgerelated to visible phenomena and events, through speaking activities, listening, reading, and writing in the realm of the concrete and abstract. There are fourabilities that are the objectives of learning in English that must be mastered by students, namelyability to read (reading), write (writing), listen (listening) andspeaking.The students still found difficulty in pronuncing the english word, the students are still lack of vocabulary, the lack of time for students to read, the books that students read are less attractive can make students bored. Students will not understand if the teacher only relies on methodsconventional (lecture method) by utilizing makeshift media such astextbook only.So that the learning objectives are expectedcan be achieved with a scientific approachlearning that is in accordance with the content of the 2013 curriculum, students are required to be active in the processlearning through observing, questioning, exploring,associate and communicate.

Digital Book (Digital Book) or Electronic Book (E-book) is, a form of book that can be opened electronically through a computer, laptop or smartphone. Digital book is a publication that consists of from text, images or sound and published in digital form can be read on a computer or device other electronic excellence and attractiveness of books digital is expected to be able to foster interest in reading so that literacy skills Indonesian society is increasing. Thus the interest in reading will increase grow.

Based on observations of students' problems, I found that when reading they often do wrong things, such as poor pronunciation, lack of vocabulary, less interesting books, and lack of time to read. With the e-book learning media, researchers argue that students will have better reading skills because e-books are an appropriate learning medium to solve these problems. Because eBooks have learning facilities that are more comfortable and fun.

"Improved Reading Comprehension of English Through Comic Media". This research is an action researchclass (Classroom Action Research) which was implementedby following the model research procedureJohn Elliot which covers planning activities(planning), action (action), observation (observation),reflection (reflection). Classroom action research isa scientific research activity carried outin a rational, systematic and empirically reflective manneragainst various actions taken byteacher or lecturer (teaching staff), collaboration(research team) as well as a researcher, sincecompiling a plan to assessmentagainst real action in the classroom which islearning activities, to improve andimprove the conditions of learning undertaken(Iskandar, 2012).

Based on the observation, the formulation in this study "is there any effect of using digital book to improve students' reading skill at the tenth grade of SMA Negeri 2 Rantau Selatan Academic year 2020/2021?" 


\section{RESEARCH METHODS}

The type of this research is quasi experiment research. According to Loewen and Plonsky (2016), in John Rogers and Andrea reversz, Experimental and quasi-experimental research designs examine whether there is a casual relationship between independent and dependent variables. Simply defined, the independent variable is the variable of influence and the dependent variable is the variable that is being influenced. The design of the research is pre and post-test design, which uses two groups as a sample. The students were administered by giving pre-test at the beginning in order to know their abilities in reading. After that they were given the treatment in the middle. During treatment, the researcher was collaborated with the observer. At the end, they were given post-test. In this research, pre-test and post-test were compared in order to determine the effect of using English ebook on students reading ability in descriptive text. The design of the research can be illustrated as follows:

Pre-test and Post-test Design

Select Control Group Pre-Test No Treatment Post-Test

Select Experimental Group Pre-Test Experimental Treatment Post-Test

Table 1. Loewen and Plonsky (2016)

The instrument in this research is test. The test was conducted in pre-test and post-test (competence test). For pre-test, the researcher give the students a paper with 4 Essay. The instruction of the paper is answer the question of the form of post-test is same as pre-test.The researcher analyzed data by counting pre-test and post-test scores, the researcher had the normality and homogeneity test to ensure that students' reading was normal and homogeneity.

The formula used in testing the hypothesis is the $\mathrm{t}$-test at the significant level $=5 \%$. To codify the control class and the experimental class.

$$
t_{\text {hitung }}=\frac{\bar{X}_{1}-\bar{X}_{2}}{\sqrt[s]{\frac{1}{n_{1}}+\frac{1}{n_{2}}}} \text { with } \quad s=\frac{(n-1) s_{1}{ }^{2}+\left(n_{2}-1\right) s_{2}{ }^{2}}{n_{1}+n_{2}-2}
$$

Explanation :

$\mathrm{t}=$ Statistical test price

$\left(\mathrm{X} \_1\right)^{-}=$Average value of the experimental sample

$\mathrm{X}_{-}^{-} 2=$ The mean value of the control sample

$\mathrm{S}=$ Sample standard deviation

$\mathrm{n} 1=$ Number of samples for the experimental class

$\mathrm{n} 2=$ The number of samples for the control class

s12 $=$ Variance in the experimental sample

s22 $=$ Variance in the control sample

The test criteria are :

Ho : thitung <thitung <, there is no influence

Ha: thitung $\geq$ thitung $<$, there is influence

Accept Ha If thitung $\geq$ ttabel

Refuse Ha If thitung <ttabel 


\section{RESULTS AND DISCUSSION}

\section{Result}

Based on the research conducted, data were obtained in the form of reading skills on the descriptive text of students from both the experimental class and the control class. The reading skills data on the descriptive text were obtained after being given a test in the sample class. The questions were given 4 questions in which the questions were declared valid because they had been tested.

\section{a. Test Validity}

4 test items in the description, it is stated that the 4 questions are valid, so that the questions are used entirely. With rcount $>$ rtable, it is stated that the question is valid, and vice versa rcount $<$ rtable then it is declared invalid. In this study rcount $>$ rtable (rcount $>0.329$ ).

\begin{tabular}{|c|c|c|c|}
\hline No & $r_{\text {count }}$ & $r_{\text {table }}$ & Description \\
\hline 1 & 0,432 & 0,329 & Valid \\
\hline 2 & 0,564 & 0,329 & Valid \\
\hline 3 & 0,546 & 0,329 & Valid \\
\hline 4 & 0,450 & 0,329 & Valid \\
\hline
\end{tabular}

b. Hypothesis testing

Table 2. Results of Test Data Validity Analysis

The hypothesis in this study was tested using the independent Sample $T$ Test. Independent Sample T Test is used to determine whether there is a difference in the average of the two samples.Hypothesis testing is done to test the one hand by using statistical $\mathrm{T}$ test. Obtained T count $=1.241$. Then compared to the price of T table in df 70 and level $\alpha=0.05$ it is 1.667. With the testing criteria are: accepted Ha if $\mathrm{T}$ count $>\mathrm{T}$ table. Since the calculation of hypothesis testing found that $\mathrm{T}$ count $=1.241$ and $\mathrm{T}$ table $=1.667$. So in this research Ho is rejected and $\mathrm{Ha}$ is accepted. In other words, there is an effect of using digital book to students reading ability in descriptive text at tenth grade students of SMA Negeri 2 Rantau Selatan.

\begin{tabular}{ccc}
\hline T count & $\mathbf{1 . 2 4 1}$ & T count $>$ T table \\
\hline T table & 1.667 & Ho $:$ REJECTED \\
\hline
\end{tabular}

Table 3. Result of Hypothesis Test

\section{Discussion Research}

The first teaching and learning process is to use a conventional model in the control class which consists of 36 students. In these learning activities, many students are still silent when asked to ask and answer questions that have been given, many students also excuse themselves from leaving the class, there are also students who sleep while learning is taking place and even many students do not care when the teacher provides the material being taught . This is because it is still unfamiliar with the research used. Whereas with the second learning process using problem-based learning models in the experimental class which consisted of 36 students as well. At this meeting, many students began to attend and pay attention, many students also began to ask questions and were active during the learning process. In the learning 
that is carried out, the researcher also finds problems or obstacles that are encountered during the learning process, namely students are not used to working on problems related to reading skills in the description text, so that adaptation and sufficient time are needed for students to get used to new learning such as those that are used. researchers apply.

In a study conducted in class X SMA Negeri 2 Rantau Selatan for the 2020-2021 academic year, it was stated that there was a significant effect of Problem-Based learning on students' reading ability in the descriptive text material in class X SMA Negeri 2 Rantau Selatan. The average result of students' reading ability using problem-based learning in the experimental class was higher than the control class that did not use the problem-based learning model. It can also be seen that the average value of the experimental class has begun to be above the average, which is above 75 , while the control class is not. From the description above, it is clear that there is an effect of problem-based learning on students' reading ability in the experimental class, namely class X-MIA2 at SMA Negeri 2 Rantau Selatan.

\section{CONCLUSION}

Based on the results and discussion of the research described above, the researchers suggest the following conclusions, namely that there is an effect of using dgital book to students reading ability in descriptive text, especially in the pronunciation in class X SMA students SMA N 2 Rantau Selatan. This is supported by the following results:

1. Digital books help students to be more active in reading and better pronunciation and confidence to speak English.

2. The previous data shows that the Hypothesis (Ha) is accepted and the Null Hypothesis (Ho) is rejected.

3. The results of the test criteria are: $\mathrm{Ha}$ is accepted if $\mathrm{T}$ count $>\mathrm{T}$ table. Due to the calculation of hypothesis testing, it was found that $\mathrm{T}$ count $=1.241$ and $\mathrm{T}$ table $=1.667$. So in this study Ho is rejected and Ha is accepted. In other words, there is no effect of using the using digital book to students reading ability in tenth graders of SMA Negeri 2 Rantau Selatan.

\section{REFERENCES}

Almara'beh et al., The Effectiveness of Multimedia Learning Tools in Education, International Journal of Advanced Research in Computer Science and Software Engg. 5(12), December- 2015, pp. 761-764

Anonimus (2014). Buku Digital (BukuSumber). SEAMOLEC: Jakarta.

Arikunto, S. 2010.Dasar-DasarEvaluasiPendidikan. Jakarta: RinekaCipta.

Arikunto, Suharsimi. 2010, ProsedurPenelitian. Jakarta: RinekaCipta.

Beimers, K. D. (2014). Correlation between Interactive EBooks and Printed Text in Reading 
Volume 1, Number 3, December 2021, Page. 93 - 99

Email : editorijhess@gmail.com

Achievement and Student Interest. Master of Education $\quad$ Program Theses. Paper 48.

Retrieved from https://digitalcollections.dordt.edu/cgi/viewcontent.cgi?article $=1047$

\&context=med_theses. 